\title{
The contribution of self-regulation and YouTube users to Risky Sexual Behavior for boarding house students
}

\author{
Risky Pratiwi ${ }^{1}$, Mudjiran Mudjiran ${ }^{1}$ \\ ${ }^{1}$ Universitas Negeri Padang
}

\begin{tabular}{l} 
Article Info \\
\hline Article history: \\
Received Jan $12^{\text {th }}, 2020$ \\
Revised Feb $28^{\text {th }}, 2020$ \\
Accepted Mar $11^{\text {th }}, 2020$ \\
\hline
\end{tabular}

\section{Keyword:}

Risky sexual behavior Self-regulation

YouTube

\begin{abstract}
Early adulthood is a time when students tend to want to know something new, including sexual behavior, the lack of information about the sexual behavior makes students engage in risky sexual behavior. The factors for risky sexual behavior are self-regulation and YouTube users. The purpose of the study is to describe the contribution of self-regulation to risky sexual behavior, the contribution of self-regulation to risky sexual behavior, and the contribution of both variables to risky sexual behavior. The population in this study was 330 students in the eastern freshwater villages of Padang city and a sample of 60 people using purposive sampling techniques. The instruments used were selfcomposed instruments, namely self-regulation instruments, YouTube users and risky sexual behavior using a Likert scale model. Data Scale model analyzed with quantitative descriptive methods, simple regression, and multiple regression. Analysis of the data showed that there was a self-regulation contribution to risky sexual behavior by $70 \%$, YouTube users' contribution to risky sexual behavior by $74 \%$, contribution self-regulation and YouTube users' to risky sexual behavior by $77.4 \%$. Based on the results of this study can later develop a program or technique in guidance and counseling that can assist students in avoiding risky sexual behavior.
\end{abstract}

(C) 2020 The Authors. Published by Redwhitepress

This is an open access article under the CC BY-NC-SA license

(https://creativecommons.org/licenses/by-nc-sa/4.0/

\section{Corresponding Author:}

Risky Pratiwi,

Universitas Negeri Padang

Email: riskipratiwibk13@gmail.com

\section{Introduction}

Sexual behavior among students is increasing, so special attention is needed from all parties including universities. Cases of unwanted pregnancies (KTD), abortions, and prenuptial sexually transmitted infections are increasingly occurring among students (Azinar, 2013).Risky sexual behavior is the leading cause of Human Immunodeficiency Virus (HIV) infection worldwide (Woerner, Kopetz, Lechner, \& Lejuez, 2016). Premarital sexual behavior can be at risk of Sexually Transmitted Diseases (STDs), Human Immunodeficiency Virus (HIV)/Acquired Immuno Deficiency Syndrome (AIDS), and out-of-wedlock pregnancies (Pane, Mudjiran, \& Daharnis, 2014).

People with HIV (Human Immunodeficiency Virus) in Padang City, West Sumatra Province (Sumbar) do not come from the local population, but rather $d$ ue to deviant sexual behavior or free sexual behavior committed by migrant settlers. Cases of HIV and AIDS were found to range from 40-48 percent in Padang city and 60 percent from outside Padang City. When viewed from the prevalence of HIV originating from Padang City only 0.14 per 100 inhabitants, said the Head of Padang City Health Office, Ferry Mulyani Hamid, Wednesday (1/22/2020) (Milna, 2020). 
The results of interviews with local youth explain that in the area there are several boarding houses that do not make special visiting hours rules, and in the eastern freshwater village of Padang City there are boarding houses that have male and female residents in the same neighborhood or the same boarding house, there are no pamphlets containing boarding house regulations that must be adhered to by each occupant of the boarding house, while the problem that occurs among at students is that there are gay and lesbian activities , but local residents have not received strong evidence to sanction the student, from the youth leader's explanation that it is not easy to trace similar sexual behavior. Today's technological advances make it easier for students to obtain information about sexual behavior from the mass media. This kind of information tends to put students at the heart of sexual problems and irresponsible sexual behavior. An erroneous understanding of sexual education can lead students to get it wrong, so students can get caught up in deviant sexual behavior (Haryani, Mudjiran, \& Syukur, 2012). Ikatan Muslim Scholars of Indonesia (ICMI) on June 08, 2016 recorded in the span of 2010-2016 Indonesia is the most diligent country to access YouTube and Google. Ironically, porn keywords are the most used keywords than educational, economic, religious, social, or political keywords (Anas, 2016).

Self-regulation also affects risky sexual behavior, self-regulation means the ability to control selfbehavior. Self-regulation is a process that activates continuous thinking, feelings, and behaviors in an effort to achieve a set goal (Susanto, 2006). The role of self-regulation also plays a role in controlling risky sexual behavior among students such as, individuals who have strong self-regulation, able to control their sexual mischief against individuals who are not partners (Gailliot \& Baumeister, 2007).

Based on the description described earlier, there is a relationship of self-regulation with risky sexual behavior, but in previous studies there has been no discussion of whether self-regulation and YouTube can jointly contribute to risky sexual behavior. happened, researchers wanted to see how student self-regulation eastern freshwater village performance, how students boarding house eastern freshwater village in using YouTube, how students charge to control themselves from risky sexual behavior, furthermore, whether selfregulation and YouTube users contribute to risky sexual behavior for students living in the eastern freshwater village of Padang City.

\section{Method}

The study used correlational and double regression methods that aimed to test the contribution of two free variables to one bound variable. The variables in this study consist of self-regulation (X1) and YouTube users (X2) which are free variables, as well as risky sexual behavior (Y) are bound variables. The population of this study is boarding house students in the eastern freshwater village of Padang city of 330 students, a sample of 60 students selected with purposive sampling techniques, using this technique because not all populations are included in the research category. The instruments used were self-composed instruments, namely selfregulation instruments, YouTube users and risky sexual behavior using a Likert scale model. Scale models analyzed with quantitative descriptive methods, simple regression and double regression. Data analysis is assisted by using the SPSS version 20.00 program.

\section{Results and Discussions}

The data in this study included self-regulation variables (X1), YouTube variables (X2), and risky sexual behavior (Y).The following is a description of the data from the study.

\section{Self-Regulation $\left(\mathbf{X}_{1}\right)$}

A description of self-regulation data can be found in table 1

Table 1. Self-regulation data

\begin{tabular}{|c|c|c|c|}
\hline Score Interval & Category & Frequency (F) & Percentage (\%) \\
\hline $88-104$ & Very high & 6 & 10 \\
\hline $71-87$ & High & 13 & 22 \\
\hline $54-70$ & Medium & 19 & 32 \\
\hline $37-53$ & Low & 17 & 28 \\
\hline \multirow[t]{2}{*}{$20-36$} & Very Low & 5 & 8 \\
\hline & Total & 60 & 100 \\
\hline
\end{tabular}

In detail from the analysis data it appeared that the highest score scoring average for students against accepted rules lies in intrinsically motivated behavioral indicators with a percentage of $62 \%$ being in the 
moderate category, then the lowest average score being on the regulatory identified indicator and the assessment with a percentage of $56.1 \%$ that is in the moderate category.

YouTube users $\left(\mathrm{X}_{2}\right)$

A description of YouTube user data can be found in table 2

Table 2. YouTube user data

\begin{tabular}{clcc}
\hline Score Interval & \multicolumn{1}{c}{ Category } & Frequency (F) & Percentage (\%) \\
\hline $90-105$ & Very high & 5 & 9 \\
\hline $74-89$ & High & 6 & 10 \\
\hline $58-73$ & Medium & 14 & 23 \\
\hline $42-57$ & Low & 21 & 35 \\
\hline $26-41$ & Very Low & 14 & 23 \\
\hline & Total & 60 & 100 \\
\hline
\end{tabular}

In detail from the data analysis it appears that the highest score of the average YouTube user lies in the total view indicator with a percentage of $59.1 \%$ being in the moderate category, then the lowest average score is in the total share indicator with a percentage of $54.3 \%$ that is in the moderate category.

\section{Risky Sexual Behavior (Y)}

A data description of Risky Sexual Behavior can be found in table 3

Table 3. Risky Sexual Behavior

\begin{tabular}{clccc}
\hline Score Interval & & Category & Frequency (F) & Percentage (\%) \\
\hline $61-71$ & Very high & 10 & 17 \\
$50-60$ & High & 6 & 10 \\
$39-49$ & Medium & 18 & 30 \\
$28-38$ & Low & 19 & 31 \\
$17-27$ & Very Low & 7 & 12 \\
\hline & Total & 60 & 100 \\
\hline
\end{tabular}

In detail from the data analysis it appeared that the highest score of the average student assessment of risky sex behavior received was on the Hug and handrail indicator with a percentage of $65.4 \%$ being in the high category, then the lowest average score was found in the Sex indicator (intercourse) with a percentage of $57.2 \%$ who were in the moderate category.

\section{Data Analysis Requirements Testing}

The analysis requirements tested on this research data are normality tests, linearity tests, and multicollinearity tests.

\section{Normality Test}

Normality testing is conducted by Kolmogorof-Smirnov method with a degree of significance of 0.05 which means the sample comes from a normal distributed population. P-value of all three variables is large from a significant level of $\alpha=0.05$.Risky sexual behavior variable (Y) of 0.123 , self-regulation variable (X1) of 0.200 . and a YouTube user variable (X2) of 0.165 .based on the description above it can be concluded that the data comes from a normal distributed population.

\section{Linearity Test}

A description of linearity test data can be found in table 4

Table 4. Linearity test data

\begin{tabular}{cccc}
\hline Variable & $\mathbf{F}$ & Level of Significance & Conclusion \\
\hline $\mathbf{X}_{1} \mathbf{Y}$ & 1.453 & 0.179 & Linear \\
\hline $\mathbf{X}_{2} \mathbf{Y}$ & 1.695 & 0.88 & Linear \\
\hline
\end{tabular}

Based on table 4 that the linearity test results show significant values that can be 0.179 and 0.088 greater than the defined significance of 0.05 , then based on the F-count value of 1,453 and 1,695 smaller than $\mathrm{f}$ table then, it can be concluded that there is a significant linear relationship between variable X1 with Y and X2 with Y. 
Multicollinearity Test

Looking at the possibility of multicollinearity used spss help version 22.00.If the value of Variance Inflation Factor (VIF) 10 or more becomes a rule of thumb to conclude VIF is too large, so it is inferred that multicollinearity occurs. Based on calculations through SPSS can be seen in table 5 .

Table 5. Multicollinearity occurs

\begin{tabular}{cccc}
\hline Variable & Tolerance & VIF & Description \\
\hline (Constant) & & & No multicolineclineity \\
$\mathrm{X}_{1}$ & 0.250 & 4.007 & \\
$\mathrm{X}_{2}$ & 0.250 & 4.007 & \\
\hline
\end{tabular}

The results of table 18 calculations show that the self-regulation VIF value is 4,007 and the YouTube user's VIF value is 4,007, thus, both VIFs are smaller than 10.That is, there is no multicollinearity between self-regulation and YouTube users.

Self-Regulation Contribution (X1) Contributes Significantly to Risky Sexual Behavior (Y)

Based on calculations through SPSS can Simple Linear Regression Analysis self-Regulation (X1) on Risky Sexual Behavior (Y) can be seen in table 6

Table 6. Simple Linear Regression Analysis self-Regulation (X1) on Risky Sexual Behavior (Y)

\begin{tabular}{cccc}
\hline Variable & $\mathbf{R}$ & Rsquare \\
\hline $\mathrm{X}_{1}$ to $\mathrm{Y}$ & 0.837 & 0.700 \\
\hline
\end{tabular}

In table 6 it appears that an $\mathrm{R}$ value of 0.837 indicates a regressive coefficient between self-regulation and risky sexual behavior. $\mathrm{R}$ Square's value is 0.700 , this indicates that $70 \%$ of risky sexual behavior can be explained by self-regulation while the rest is explained by other variables.

YouTube User Contributions (X2) Contribute Significantly to Risky Sexual Behavior (Y)

YouTube users' regression analysis of risky sexual behavior can be found in table 7.

Table 7. YouTube users' regression analysis of risky sexual behavior

\begin{tabular}{cccc}
\hline Variable & $\mathbf{R}$ & R Square \\
\hline $\mathrm{X}_{2}$ to $\mathrm{Y}$ & 0.861 & 0.742 \\
\hline
\end{tabular}

In table 7 it appears that an $\mathrm{R}$ value of 0.861 indicates a regression coefficient between YouTube users against risky sexual behavior. $\mathrm{R}$ Square's rating is 0.742 , this indicates that $74 \%$ of risky sexual behavior can be explained by YouTube users, while the rest is described by other variables.

The Contribution of Self-Regulation (X1) and YouTube Users (X2) Together Contribute Significantly to Risky Sexual Behavior (Y)

The results of self-regulation analysis (X1) and YouTube users (X2) together against risky sexual behavior (Y) can be found in table 8 below.

Table 8. The results of self-regulation analysis (X1) and YouTube users (X2) together against risky sexual behavior $(\mathrm{Y})$

\begin{tabular}{ccc}
\hline Variable & $\mathbf{R}$ & RSquare \\
\hline $\mathrm{X}_{1}, \mathrm{X}_{2}$ to $\mathrm{Y}$ & 0.880 & 0.774 \\
\hline
\end{tabular}

According to Table 25, R's double regression coefficient of $0.880, \mathrm{R}$ Square's coefficient of 0.774 , meaning that $77.4 \%$ of risky sexual behavior can be explained by self-regulation and YouTube users, the rest coming from other Variables as in the identification of previous problems.

\section{Self-Regulation}

The overall sample of 60 students, there are 6 students whose self-regulation is in a very high category or can be percentage $10 \%$, there are 13 students who are self-regulated in the high category or can be percentage $22 \%$, there are 19 students whose self-regulation is in the moderate category or can be percentage $32 \%$, there are 17 students who self-regulation is in the low category or can be percentage $28 \%$, whereas for very low categories there are 5 people or can be presented 8\%.Self-regulation affects risky sexual behavior among students. Selfregulation is the process by which a person activates and nurtures his thoughts, feelings, and actions to achieve personal goals (Husna, N.R.Hidayati, \& Ariati, 2004). Self-regulation is an individual's ability to motivate themselves to achieve goals by planning, evaluating, and modifying individual behaviors themselves. Selfregulation is not only formed to achieve goals, but seeks to avoid environmental disturbances and emotional 
stimuli that can interfere with individual development (Pervin \& Oliver, 2005).Ghufron \& Risnawati (2011) explained there are three factors that affect self-regulation. namely: 1)individual, 2) Behavior, 3) Environment. Brown \& Ryan propose some form of regulation based on the theory of self-determination (Chairani \& Subandi, 2010) namely: 1) Amotivation regulation, 2) External regulation, 3) Introjected regulation, 4) Identified regulation, 5) Intrinsically motivated behavior. based on the analysis of the highest score data the average assessment of students against self-regulation received lies in the Intrinsically motivated behavior indicator with a percentage of $62 \%$. From the findings described earlier, lecturers University can compile a program with materials related to the indicators that have been found.

\section{YouTube users}

The overall sample sample of 60 students, there are 5 students who in terms of YouTube users are categorized as very high or can be $9 \%$ percent, there are 6 students who in terms of YouTube users are categorized as high or can be $10 \%$ percent, there are 14 students who in terms of YouTube users are categorized as moderate or can be $23 \%$ percent, there are 21 students who in terms of YouTube users are categorized as low or can be presented $35 \%$, and there are 14 students who in terms of YouTube users are categorized as very low or can be presented $23 \%$. YouTube users influence risky sexual behavior among students.

YouTube is an internet site that provides a wide range of video content(Maharani \& Parwata, 2019). According to Budiargo (2015:47) YouTube is an online video, the main use of this site is as a medium to search, view and share original videos from all corners of the world through a web(David, Sondakh, \& Harilama, 2017). Researchers chose YouTube as a variable to be researched because students in the millennial era are not separated from social media one of them is YouTube, which contains video content that can partly stimulate sexual arousal.

Faiqah, Nadjib, \& Amir (2016)explaining there are characteristics of YouTube that make many of the users very often use it, grouped into 5 parts: 1) There is no time limit to uploading videos, 2) Security system that starts accurately, 3) Paid, 4) Offline system, 5) Simple editor available. Wirga (2016)YouTube has Channel features, this feature is like a broadcast channel on television or on a radio broadcast, wirga classify YouTube channel namely; (a) CP : Popular Channels; (b) Sc : Total subscribers; (c) Vc : Total view; (d) Shc: Total share. Based on the data analysis obtained the highest score scoring average YouTube users are located in the total view indicator with a percentage of $59.1 \%$. From the findings described earlier, lecturers at University can compile a program with materials related to the indicators that have been found.

\section{Risk Sexual Behavior}

Sample of 60 students, there are 10 students whose risky sexual behavior is in the very high category or can be percentages $17 \%$, there are 6 students whose sexual behavior is at risk of being in a high category or can be percentage $10 \%$, there are 18 students whose sexual behavior is at risk of being in the moderate category or can be percentage $30 \%$, there are 19 students whose sexual behavior is at risk of being in the low category or can be percentage $31 \%$, while for very low categories there are 7 people or can be presented $12 \%$. Risky sexual behavior affects risky sexual behavior among students.

Delavita \& Ningsih (2019)explaining that sexual behavior is all behaviors driven by sexual desire, both with the opposite sex and the same sex. Sexual behavior that is any form of behavior driven by same-sex or opposite sex sexual desire (Sham et al., 2017). Hurlock (2009) revealed that sexual activity is a form of dating behavior or an expression of love (Aprilia \& Ningsih, 2009). Risky sexual behavior is that they have sexual intercourse, having sex without a condom with many couples who may carry a high risk, such as prostitutes. This puts them at high risk of unwanted pregnancies, abortions and sexually transmitted diseases, including HIV (Situmorang, 2003). Risky sexual behavior is the leading cause of Human Immunodeficiency Virus (HIV) infection worldwide(Woerner et al., 2016).Risky sexual behavior is common among both students and adults starting with prenuptial sexual behavior. Prenuptial sexual behavior is all behavior spurred by sexual desires committed by two men and a woman in the absence of a valid marital bond (Sarwono, 2005). Prenuptial sexual behavior in students is influenced by many factors such as hormonal changes, free association, and the student's lack of understanding of sexual maturity as well as lack of information about sexuality (Sari \& Karneli, 2019).

Sarwono (2012)describes forms of sexual behavior into 4 kinds: 1)Hugs \& handrails, 2) Kissing, 3) Groping breasts or genitals, 4) Intercourse (intercourse), i.e. sexual activity where penile penetration occurs into the vagina for sexual gratification. Blegur (2017)explaining the form of student sexual behavior is as follows: 1) Touching, 2) Kissing, 3) Necking, 4) Petting, 5) Oral sex, 6) Sexual intercrouse, 7) Unwanted pregnancies. Sarwono (2012)explains that sexual behavior can cause mental tension and confusion about the social role that suddenly changes if a girl suddenly conceives. 
Based on the analysis of data it appears that the highest score of the average student's assessment of accepted risky sexual behavior sits on the Hug and handrail indicator with a percentage of $65.4 \%$. From the findings explained earlier, lecturers in universities devise programs with materials related to indicators that have been found.

\section{Conclusions}

Based on the findings and discussion of the results of the study, it can be presented the following conclusions: 1) On average the self-regulation of students boarding house at Padang city in the moderate category, 2) On average YouTube users of students boarding house at Padang City in the low category, 3) On average risky sexual behavior of students boarding house at Padang City in the moderate category, 4) Selfregulation contributes significantly to risky sexual behavior in students by $70 \%$. This means that the worse student self-regulation will be, the worse student risky sexual behavior will be, 4) YouTube users contribute significantly to $74 \%$ of students' risky sexual behavior. This means that the worse a student's YouTube use will be, the worse student risky sexual behavior will be, 5) Risky sexual behavior contributes significantly to student self-regulation and YouTube users by $77.4 \%$. This means that the worse the contribution of selfregulation and student Use of YouTube the worse the student's risky sexual behavior will be.

\section{References}

Anas, A. (2016). ICMI asks the government to block YouTube and Google, what's the reason? Liputan6.com. Retrieved from https://www.liputan6.com/citizen6/read/2525934/icmi-minta-pemerintah-blokirYouTube-dan-google-apa-sebabnya

Aprilia, R., \& Ningsih, Y. T. (2009). Differences in sexual behavior are reviewed from the style of love in adolescents who are dating. Journal of Psychological Research, 1(3).

Azinar, M. (2013). Prenuptial sexual behavior is at risk for unwanted pregnancies. Journal of Public Health, $8(2), 153-160$.

Blegur, J. (2017). Preference for adolescent sexual behavior. Journal of Projection, 11(2), 9-19.

Chairani, L., \& Subandi., M. . (2010). Psychology of memorizing the Qur'an (the role of self-regulation). Yogyakarta: Student Library.

David, E. R., Sondakh, M., \& Harilama, S. (2017). The influence of Vlog Content in YouTube on the Establishment of Communication Science Students Faculty of Social and Political Sciences Sam Ratulangi University. Journal of Acta Diurna, VI(1).

Delavita, N., \& Ningsih, Y. T. (2019). Differences in sexual behavior are reviewed from foster patterns in high school teens who are dating. Journal of Psychological Research, 1(3), 1-12.

Faiqah, F., Nadjib, M., \& Amir, A. S. (2016). YouTube as a means of communication for makassar vidgram community. Kareba Journal of Communication, 5(2), 259-272.

Gailliot, M. T., \& Baumeister, R. F. (2007). Self-regulation and sexual restraint: dispositionally and temporarily poor self-regulatory abilities contribute to failures at restraining sexual behavior. Personality and Social Psychology,Inc., 33(2), 173-186.

Ghufron, M., \& Risnawati, N. R. (2011). Psychological theories. Yogyakarta: Ar-Ruzz Media.

Haryani, M., Mudjiran, \& Thanksgiving, Y. (2012). The Impact of Pornography on Student Behavior and the Efforts of Mentoring Teachers to Overcome It. Scientific Journal of Counseling, 1(1), 1-8.

Husna, A. N., N.R.Hidayati, F., \& Ariati, J. (2004). Self-regulation is an achievement. Journal of Psychology Undip, 13(1).

Maharani, D. K. L., \& Parwata, I. G. N. (2019). Copyright protection against the use of songs as video backgrounds on the YouTube site. Kertha Semaya Journal, 7(10), 1-14.

Milna. (2020). Throughout 2019, 287 cases of HIV were found in Padang City, the majority of the population of migrants. Harianhaluan.com.

Pane, R. M., Mudjiran, \& Daharnis. (2014). Development of Guidance and Counseling Module for Prevention of Prenuptial Sexual Behavior of High School Students ( SMA ). Counselor's Journal, 3(3).

Pervin, \& Oliver. (2005). Personality theory and researched 9th. United state of America: John Wiley \& Sons, Inc.

Sari, L. E., \& Karneli, Y. (2019). Students perception of premarital sexual behavior among adolescents and implications for guidance and counseling services. Journal of Neo Counseling, 1(2), 1-7. https://doi.org/10.24036/00110kons2019

Sarwono, P. (2005). Obstetrics. Jakarta: Yayasan Bina Pustaka.

Sarwono, S. W. (2012). Adolescent Psychology. Jakarta: King Grafindo Persada.

Sham, F. M., Mud, S. C., ALi, M. M., Kusrin, Z. M., Rasit, R. M., \& Muhammad, S. N. (2017). Sharia 
guidelines for Parents addressing the sexual behavior of adolescents with autism. Journal of Hadhari Special Edition, 169-182.

Situmorang, A. (2003). Adolescent reproductive health in Indonesia. Jakarta: Johns Hopkins University.

Sahu. (2006). Development of self regulation skills to improve students' academic success. Journal of Sower Education, 5(7), 64-71.

Wirga, E. W. (2016). Analysis of content on social media YouTube videos to support political campaign strategies. Jurna; Scientific Informatics And Computers, 21(1), 14-26.

Woerner, J., Kopetz, C., Lechner, W. V, \& Lejuez, C. (2016). The role of rejection sensitivity and the need to belong. Addictive Behaviors. https://doi.org/10.1016/j.addbeh.2016.06.006 